\title{
JIE
}

JOURNAL OF ISLAMIC EDUCATION

Vol. 7 No. I Mei 2022

P-ISSN 2503-5363; E-ISSN 2528-0465

http://www.ejournal.stitmuhbangil.ac.id/index.php/jie

\section{Penerapan Protokol Kesehatan pada Masyarakat Sukodono dalam Perspektif Islam dan Sosial Kemasyarakatan}

\author{
*Khanjun Azenno ${ }^{1}$, Aldorama Satriagung Aziz ${ }^{2}$, Imamul Arifin ${ }^{3}$ \\ 1,2,3 (Politeknik Elektronika Negeri Surabaya, Jl. Raya ITS, \\ Keputih, Sukolilo, Surabaya, Indonesia) \\ *khanjungan@gmail.com
}

\begin{tabular}{l} 
Informasi Artikel \\
\hline Received: \\
1 December 2021 \\
Accepted: \\
18 January 2022 \\
Published: \\
6 May 2022 \\
Keywords: \\
The Covid-19 Pandemic, \\
Implementation of Health, \\
Islamic and Social \\
Protocols.
\end{tabular}

\begin{abstract}
This study aims to open the community's mindset to their response to Covid-19 from the point of view of Islam, social society, and science to end the Covid-19 pandemic. This research uses qualitative methods and case studies. The data were obtained from the results of surveys, interviews, observations, and analysis of the substance under investigation and added data from the literature as a reference. The study results show that people's mindsets can affect the spread of the Covid-19 virus because this wrong mindset will result in those who underestimate the virus so that it spreads more widely. Therefore, it is necessary to instil an understanding that ending this pandemic requires an open mind to all solutions provided by the government because the government always provides the best solutions for its people, such as implementing Health protocols and vaccinations.
\end{abstract}

Penelitian ini bertujuan untuk membuka pola pikir masyarakat terhadap responnya terhadap Covid19 dari sudut pandang Islam, sosial kemasyarakatan, dan ilmu pengetahuan, guna mengakhiri pandemi Covid-19. Penelitian ini menggunakan metode kualitatif dan studi kasus. Data diperoleh dari hasil survei, wawancara, observasi, dan analisis terhadap substansi yang diteliti, serta penambahan data dari literatur sebagai referensi. Hasil penelitian menunjukkan 


bahwa pola pikir masyarakat dapat
mempengaruhi penyebaran virus Covid-19,
karena pola pikir yang salah ini akan
mengakibatkan perilaku mereka yang
meremehkan virus sehingga penyebarannya
semakin luas. Oleh karena itu, perlu ditanamkan
pemahaman bahwa mengakhiri pandemi ini
membutuhkan pikiran yang terbuka terhadap
semua solusi yang diberikan oleh Pemerintah
karena pemerintah selalu memberikan solusi
terbaik bagi masyarakatnya, seperti menerapkan
protokol Kesehatan dan vaksinasi.

\section{PENDAHULUAN}

Diawal tahun 2020, dunia digemparkan dengan merebaknya virus baru yaitu coronavirus jenis baru (SARS-CoV-2) dan penyakitnya disebut Coronavirus disease 2019 (COVID-19) (Yuliana, 2020). Virus Covid-19 atau corona merupakan virus yang menyerang saluran pernafasan atas yang menimbulkan gejala seperti flu, batuk dan demam (Sharot, 2011). Virus ini merupakan virus yang dapat menular dimana penularannya dapat melalui droplet atau cairan dalam tubuh penderitanya. Proses penyembuhan virus ini juga cukup memakan waktu yang lama berkisar 14 hari. Diketahui virus ini berasal dari Wuhan, Tiongkok, China (Law et al., 2020). Ditemukan virus ini pada akhir Desember tahun 2019 (Nicola et al., 2020).

Kemudian sampai saat ini sudah dipastikan terdapat 65 negara yang telah terjangkit virus saat ini. Pada Indonesia sendiri pemerintahan telah mengeluarkan tentang perihal darurat bencana COVID-19 terhitung mulai tanggal 29 Februari 2020 hingga 29 Mei 2020. Dimana langkah yang telah dilakukan oleh pemerintah untuk dapat menyelesaikan kasus virus ini, salah satunya adalah dengan mensosialisasikan atau menerapkan gerakan Social Distancing. Konsep ini dijelaskan bahwa untuk dapat mengurangi bahkan memutus mata rantai infeksi COVID-19 seseorang harus dilakukan antara lain menjaga jarak aman antar manusia minimal 2 meter, dan tidak melakukan kontak langsung dengan orang lain, dan menghindari pertemuan massal di tempat keramaian (Paramadina, 2021). Penyebaran virus corona dapat terjadi dimanapun salah satunya yaitu di pasar (Alda, 2020). Penyebaran virus corona di daerah yang ramai terbilang cukup 
tinggi mengingat tempat fasilitas umum merupakan tempat yang tidak pernah sepi orang sehingga social distancing sulit dilakukan di tempat ini (Buana, 2020). Penyebaran virus tersebut dapat terjadi contohnya pada saat pengunjung berada di pasar, maupun pada saat berada di mall. Pengungjung tidak akan sadar telah terinfeksi corona merupakan orang-orang yang berpotensi tinggi dalam menyebarkan virus ini. Oleh karena itu untuk mengantisipasi masalah ini, International Health Regulation/IHR melakukan kegiatan karantina, pemeriksaan alat angkut, pengendalian vektor serta tindakan penyehatan.

Data sebaran kasus Covid-19 yang dimiliki oleh Gugus Tugas Percepatan Penanganan Covid-19 (2020) mencatat bahwa Provinsi Jawa Timur berada di urutan kedua secara nasional jumlah kasus Covid-19. Berita tersebut tentu menjadi perhatian besar bagi Pemerintah Provinsi Jawa Timur untuk mengajak masyarakatnya agar waspada terhadap Covid-19. Namun, masih banyak masyarakat yang masih tidak terlalu peduli dengan Covid-19 sehingga jumlah kasus positif Covid-19 masih terus bertambah. Edukasi terkait bahaya Covid-19 harus terus dilakukan tanpa henti untuk menumbuhkan kesadaran masyarakat agarmematuhi protokol kesehatan yang ditetapkan pemerintah (Alvian \& Laudry, 2020). Dengan mematuhi protokol kesahatan, masyarakat tentu masih tetap diperbolehkan menjalankan aktivitas seperti biasa disamping tetap mencegah penularan Covid-19 (Artama et al., 2021).

Memang benar banyak sekali pihak yang dirugikan, bahkan dampaknya bagi negara juga sangat besar (Purnamasari \& Rahayani, 2020). Salah satu dampak yang paling besar adalah pada bidang ekonomi dimana terjadi kesusahan dalam mencari lapangan pekerjaan, banyak pekerja yang di PHK, susah untuk memenuhi kebutuhan hidup sehari-hari, dan juga tidak mempunyai penghasilan dalam memenuhi kebutuhan untuk sehari-hari (Hanoatubun, 2020). Banyak sekali penyesuaian ulang yang dilakukan dan hingga pada akhirnya diberlakukan WorkFrom-Home. Walau demikian, ada banyak hal positif yang dapat diambil bagi para pegawai yaitu menghemat pengeluaran seperti ongkos transportasi dan ongkos makan, dan lagi karena bekerja dirumah membuat semakin dekat dengan keluarga (Setyawan \& Lestari, 2020). Kemudian juga terdapat beberapa 
kelemahan yaitu tidak siapnya sikap dan kedisiplinan pegawai dalam pelaksanaan WFH (Suspahariati \& Susilawati., 2020). Kelemahan lainnya dari pelaksanaan WFH yaitu akan memiliki dampak seperti resiko cedera fisik maupun mental seperti keluhan muskoskeletal dan gejala stress (Fadillah, 2021).

Belum lagi dalam segi pendidikan, penutupan sementara lembaga pendidikan sebagai upaya menahan penyebaran pendemi covid-19 di seluruh dunia berdampak pada jutaan pelajar, tidak kecuali di Indonesia (Nasir \& Prastowo, 2021). Gangguan dalam proses belajar langsung antara siswa dan guru dan pembatalan penilaian belajar berdampak pada psikologis anak didik dan menurunnya kualitas keterampilan murid (Aji, 2020). Beban itu merupakan tanggung jawab semua elemen pendidikan khususnya negara dalam memfasilitasi kelangsungan sekolah bagi semua steakholders pendidikan guna melakukan pembelajaran jarak jauh (Ikhwan et al., 2021).

Manusia senantiasa melakukan hubungan dan pengaruh timbal balik dengan manusia yang lain dalam rangka memenuhi kebutuhan dan mempertahankan kehidupannya (Anwar, 2022);(Sa'adi, 2020). Namun karena adanya covid-19, kita harus menyesuaikan ulang cara berinteraksi kita ke orang lain mengingat Covid-19 adalah salah satu wabah yang sangat berbahaya yang bahkan tersebar hampir seluruh dunia. Proses penyebaran virus covid-19 ini amat cepat dan sekaligus mematikan. Walau demikian, banyak sekali warga negara Indonesia tidak memahami betapa mengerikannya virus ini dan mengabaikan protokol kesehatan yang berlaku. Sehingga banyak warga yang taat protokol kesehatan menjadi ikut kena imbasnya (Pinasti, 2020).

Cara agar kita dapat terbebas dari virus ini ialah kita semua harus satu suara. Warga kita harus satu suara yaitu harus taat prokes. Kita harus mengorbankan ego kita sementara dan menghargai satu sama lain agar dapat terlepas dari wabah ini. Salah satu langkah yang dapat kita lakukan adalah dengan menghindari atau membatasi aktifitas agar menurunkan angka penyebaran covid-19. Namun memang tetap saja terdapat orang-orang yang sulit diatur dan lebih mementingkan ego mereka. Mereka berpikir bila beraktivitas, misal dalam rangka ibadah, tidak mestinya takut akan penyakit. Al-Qur'an telah 
memberi penjelasan bahwa baik menurut kita belum tentu baik menurut Allah SWT.

Pemerintah juga telah menghimbau masyarakatnya dan telah mengerahkan segala usaha. Semua dilakukan untuk satu tujuan yaitu untuk memutus tali penyebaran Covid-19 ini. Namun, tetap saja ada beberapa masyarakat yang mengabaikannya. Padahal dalam islam dikatakan harus taat kepada pemimpin karena bentuk ketaatan kepada pemimpin ini memiliki sifat mutlak selagi tak untuk melakukan kemaksiatan (Lufaefi, 2020);(Wiranti et al., 2020). Dalam hadist juga dikatakan tidak boleh membahayakan nyawa orang lain. Kemudian ada Hifdzun Nafs, maksudnya adalah menjaga nyawa manusia lain (Maryano \& Sholeh, 2021). Pada intinya kita harus menjaga nyawa, baik itu nyawa kita maupun nyawa orang lain (Nashrullah, 2020). Sebab nyawa ini hanya titipan semata dan wajib untuk kita jaga.

\section{METODE PENELITIAN}

Penelitian ini menggunakan metode kualitatif. Metode kualitatif disini lebih ditekankan pada fenomena dan lebih meneliti ke substansi makna dari fenomena tersebut. Metode kualitatif berhubungan dengan ide, persepsi, pendapat, atau kepercayaan orang yang diteliti, kesemuanya tidak dapat diukur dengan angka. Penelitian kualitatif pada umumnya dirancang untuk memberikan pengalaman senyatanya dan menangkap makna sebagaimana yang tercipta di lapangan peneitian melalui interaksi langsung antara peneliti dan yang diteliti. Dan menggunakan metode studi kasus, dimana studi kasus adalah salah satu metode penelitian dalam ilmu sosial. Penelitian yang dilakukan terfokus pada suatu kasus tertentu untuk diamati dan dianalisis secara cermat sampai tuntas. Kasus yang dimaksud yaitu mempelajari secara intensif seorang individual atau kelompok yang mengalami kasus tertentu. Studi kasus dimaksudkan untuk mengetahui mengapa individu melakukan apa yang dia lakukan (Ikhwan, 2021).

Alasan menggunakan metode penelitian kualitatif dan studi kasus sebab dalam mendapatkan data diperlukan adanya wawancara dan pengamatan secara langsung kejadian di lapangan. Disisi lain, pengumpulan data menggunakan metode ini lebih fleksibel karena data studi kasus dapat diperoleh dari semua 
91 JIE (Journal of Islamic Education)

e-ISSN: 2528-0465 (online) | Volume 7, Issue 1 | December-May 2022

p-ISSN: 2503-5363 (print)

pihak yang bersangkutan, dengan kata lain masyarakat yang berada di lingkup daerah yang pernah rawan Covid-19. Dan untuk lokasi penelitian berada di kecamatan Sukodono, Sidoarjo, Jawa Timur.

\section{TEMUAN DAN PEMBAHASAN}

Pandemi Virus Corona adalah pandemi yang menyerang seluruh dunia. Selain penyebarannya yang sangat cepat, infeksi ini juga berbahaya. Hingga saat ini hampir 212 juta orang di seluruh dunia telah terkontaminasi virus corona dan lebih dari 4,4 juta telah kehilangan nyawa. Bahkan di Indonesia, jumlah kasus lengkap sudah mencapai 3,98 juta dan korban jiwa mencapai 127 ribu.

Jelas, otoritas publik telah mengerahkan berbagai upaya dan pendekatan, mulai dari PSBB hingga PPKM seperti sekarang. Semua upaya dilakukan secara maksimal namun pada saat yang sama ada oknum-oknum masyarakat yang mengabaikannya sehingga pendekatan tidak dapat dilaksanakan secara ideal.

\section{Perintah Patuh pada Pemimpin}

Dalam Islam ada keharusan untuk patuh pada pemerintah. Ketaatan pada pemimpin merupakan jenis kewajiban yang tidak dapat ditawar dalam kondisi apapun asalkan tidak melakukan hal-hal yang menyinggung kemaksiatan. Sebagai hasil dari komitmen ini, Nabi Muhammad SAW juga memberi perintah berupa kewajiban untuk patuh kepada pemimpin. Sebagaimana dijelaskan dalam HR. Muslim no. 1835, yang artinya:

"Barangsiapa mentaatiku, maka ia berarti mentaati Allah. Barangsiapa yang tidak mentaatiku berarti ia tidak mentaati Allah. Barangsiapa yang taat pada pemimpin berarti ia mentaatiku. Barangsiapa yang tidak mentaatiku berarti ia tidak mentaatiku."(HR. Bukhari no. 7137 dan Muslim no. 1835).

Kemudian dalam HR. Bukhari no. 7056 dan Muslim no. 1709, yang artinya:

"Nabi shallallahu 'alaihi wa sallam berdakwah kepada kami dan kami pun berbaiat kepada beliau. Maka Nabi mengatakan di antara poin baiat yang beliau ambil dari kami, Nabi meminta kepada kami untuk mendengar dan taat kepada penguasa, baik (perintah penguasa tersebut) kami bersemangat untuk mengerjakannya atau kami tidak suka mengerjakannya, baik (perintah penguasa tersebut) diberikan kepada kami dalam kondisi sulit (repot) atau dalam kondisi mudah (lapang), juga meskipun penguasa tersebut mementingkan diri sendiri (yaitu, dia mengambil hak rakyat untuk kepentingan dirinya sendiri dan kroni-kroninya, pen.), dan supaya kami tidak 
merebut kekuasaan dari pemegangnya (maksudnya, jangan memberontak, pen.). Kecuali jika kalian melihat kekafiran yang nyata (tampak terangterangan atas semua orang, pen.), dan kalian memiliki bukti di hadapan Allah Ta'ala bahwa itu adalah kekafiran." (HR. Bukhari no. 7056 dan Muslim no. 1709).

Dalam hadits di atas ditegaskan bahwa taat kepada pemimpin adalah wajib dan mulia. Poin yang dapat ditarik ialah bahwa mematuhi pemimpin adalah bentuk ibadah yang berbuah pahala. Jadi jangan merasa bahwa ini adalah ketaatan biasa, karena patuh pada pemimpin itu adalah perintah dari Rasulullah SAW. Kemudian, barangsiapa yang mematuhi Rasul Allah berarti dia mentaati Allah karena Rasulullah SAW memerintahkan untuk patuh dan taat kepada Allah SWT. Allah juga memerintahkan untuk mematuhi Nabi Muhammad SAW. Namun, banyak penduduk yang tidak memperhatikan perintah dari pemimpin. Hal ini umumnya dipicu oleh adanya kesempatan mereka tidak diawasi langsung oleh Satuan Petugas Covid. Mereka melakukannya hanya karena takut diberi hukuman, bukan karena takut akan penyebaran virus Corona. Cara berpikir inilah yang harus dirubah agar dapat membentuk pribadi yang lebih baik.

Pola pikir ini dapat tercipta karena dipengaruhi oleh banyak faktor (Blanchette \& Richards, 2010). Konsep yang paling menggambarkan perilaku masyarakat Indonesia saat ini adalah bias kognitif. Bias kognitif sendiri adalah kondisi dimana terdapat kesalahan sistematis dalam berpikir, memproses, dan menafsirkan informasi, sehingga kemudian memengaruhi cara mereka menilai serta mengambil keputusan. Bias kognitif kerap muncul sebagai hasil dari upaya otak dalam menyederhanakan informasi yang diterima (Permana, 2021). Kondisi ini membuat seseorang menjadi menganggap dirinya cenderung tidak terdampak hal negatif. Dalam bentuk lainnya, kondisi ini juga membuat seseorang tidak mau menerima fakta nyata yang negatif dan memberikan dampak buruk pada mental, tetapi malah mempercayai hal yang terkesan positif dan menyenangkan yang bahkan ada bukti yang bertentangan. Konsep berpikir seperti inilah yang membuat kita terus jatuh ke lubang yang sama sehingga sulit lepas dari belenggu Covid-19 yang masih merajalela hingga saat ini (Corbuzer, 2021). 
93 JIE (Journal of Islamic Education)

e-ISSN: 2528-0465 (online) | Volume 7, Issue 1 | December-May 2022

p-ISSN: 2503-5363 (print)

\section{Kekeliruan Pola Pikir Masyarakat terhadap Pandemi Covid-19}

Sebagaimana yang kita sadari, pola pikir seperti ini dapat membahayakan banyak nyawa. Karena pola pikir ini secara tidak sadar akan berbuah kepada perilakunya dimana mereka meremehkan virus ini dan secara tidak langsung juga meremehkan nyawa manusia. Sebagai muslim, pola pikir kita adalah menghargai nyawa pemberian dari Allah. Sebagaimana dijelaskan dalam HR. Ibnu Abbas dan Abu Said Sa'd, yang artinya:

"Tidak Boleh Melakukan Sesuatu Yang Membahayakan Diri Sendiri Ataupun Orang Lain." (HR. Ibnu Majah, no. 2340 dan no. 2341).

Dari sini dapat kita ketahui bahwa dharar (melakukan sesuatu yang membahayakan) dilarang di dalam syari'at ini. Maka, tidak halal bagi seorang Muslim mengerjakan sesuatu yang membahayakan dirinya sendiri atau orang lain, baik berupa perkataan atau perbuatan, tanpa alasan yang benar. Dan semakin kuat larangan tersebut jika dharar itu dilakukan kepada orang-orang yang wajib dipergauli secara baik, seperti kerabat, isteri, tetangga, dan lainnya. Dan usaha yang paling tepat untuk mengurangi penyebaran virus Covid-19 ini ialah dengan taat prokes dan social distancing, serta membatasi aktivitas sosial.

Dengan menghindari atau membatasi aktifitas seperti ini dapat menurunkan angka penyebaran covid-19. Memang ada pedagang dan ojol yang pemasukannya harian, perlu untuk keluar rumah saat itu juga. Dan untuk kegiatan seperti sholat berjamaah di masjid, perkumpulan digereja, dan sebagainya dapat ditunda dan digantikan di rumah (Yunus \& Rezki, 2020). Namun memang tetap saja terdapat orang-orang yang sulit diatur dan lebih mementingkan ego mereka. Mereka yakin bila pergi dalam rangka ibadah, tidak mestinya takut akan penyakit (Perdana, 2020). Al qur'an telah memberi penjelasan bahwa baik menurut kita belum tentu baik menurut Allah SWT. Sebagaimana dijelaskan dalam QS. Al-Baqarah ayat 216:

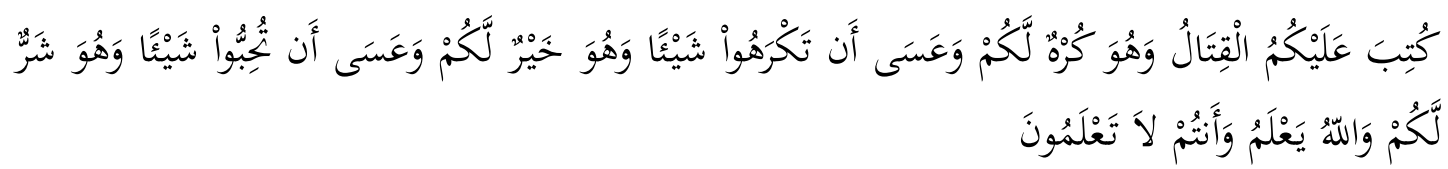

"Diwajibkan atas kamu berperang, padahal itu tidak menyenangkan bagimu. Tetapi boleh jadi kamu tidak menyenangi sesuatu, padahal itu baik bagimu, dan boleh jadi kamu menyukai sesuatu, padahal itu tidak baik bagimu. Allah mengetahui, sedang kamu tidak mengetahui."(QS. al-Baqarah 2: 216). 
Dalam ayat ini ditegaskan bahwa sesuatu yang disukai oleh kita belum tentu baik dimata Allah. Kita harus berpikir secara objektif, karena dengan perilaku kita yang didasari oleh ego juga dapat menyakiti dan bahkan membunuh orang disekitar kita secara tidak sadar (Aditya, 2014). Dan kita tau juga, salah satu dari lima hal yang wajib dijaga dalam islam ialah Hifdzun Nafs yaitu menjaga nyawa manusia, mencegah sebelum terjadi hal yang tidak diinginkan dengan mengambil tindakan preventif (Fira, 2021). Kemudian dengan tegas Allah SWT telah mengharamkan membunuh bahkan mengancam pelakunya dengan ancaman yang sangat tegas, kekal dalam Neraka Jahanam, mendapatkan murka dan laknat Allah. Sebagaimana dijelaskan dalam Surat an Nisa:

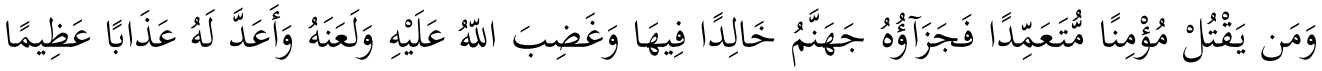

"Dan barangsiapa membunuh seorang yang beriman dengan sengaja, maka balasannya ialah neraka Jahanam, dia kekal di dalamnya." (QS. an-Nisa 4: 93).

Selain menjaga diri orang lain, dalam islam juga diwajibkan menjaga dirinya sendiri. Sebab badan dan nyawa ini bukan milik kita seutuhnya melainkan titipan, amanah, milik Allah sepenuhnya, kita wajib menjaganya. Untuk membenahi pola pikir yang kacau ini dapat dilakukan melalui beberapa cara. Pertama menghindari membuat keputusan secara terburu-buru, karena manusia cenderung tidak bijak dalam mengambil keputusan bila hanya dengan waktu yang singkat. Kedua harus berhati-hati mengambil keputusan pada kondisi bahagia, karena faktanya ketika seseorang dalam keadaan bahagia, akan membuat keputusannya menjadi kurang objektif dan pandangan mereka akan menyempit pada hal positif saja. Ketiga berpikir berdasarkan fakta dan data yang sudah ada, dengan demikian pemikiran kita akan menajam dan menjadi luas sehingga mengurangi kesalahan dalam mengambil keputusan.

\section{Bentuk Menjaga Diri dari Covid-19 dengan Vaksinasi}

Vaksinasi Covid-19 merupakan bentuk upaya dari pemerintah untuk menangani pandemi Covid-19. Tujuan dari vaksinasi singkatnya ialah untuk membentuk sistem imunitas tubuh dan mencegah terbentuknya mutasi baru dari Covid-19, agar masyarakat dapat lebih produktif dalam melakukan kegiatan 
sehari-hari (Barak, 2006);(Nugroho \& Hidayat, 2021). Lagipula vaksin COVID-19 telah melewati berbagai uji klinis. Dalam uji klinis itu, semuanya menunjukkan hasil yang menjanjikan dengan berbagai tingkat efektivitas dalam aspek perlindungan dan aspek keamanan yang aman, dimana kemampuan tubuh dalam merespon vaksin Covid-19 ini baik. Pada imunisasi dosis kedua memberikan respon imun tubuh yang lebih kuat pada semua vaksin sehingga efektivitasnya pun ikut meningkat (Santoso, 2021).

Dalam kutipan referensi jurnal, dikatakan bahwa keamanan vaksinasi telah memenuhi standart keamanan, dimana setelah melakukan vaksinasi tidak mengakibatkan efek samping yang serius. Namun, kebanyakan masyarakat ragu dan bahkan menolak melakukan vaksinasi karena khawatir akan keamanan dan efektivitasnya, dimana sebanyak $7,6 \%$ menolak dan $27 \%$ ragu-ragu. Alasan dibalik penolakan dan keraguan mengenai vaksin tersebut sangatlah beragam, seperti tidak yakin terhadap keamanan vaksin, ragu terhadap efektivitas vaksin, takut terhadap efek samping vaksin, tidak mempercayai kegunaan vaksin, dan karena keyakinan agama. Data ini didapat dari survei yang dilakukan oleh Kementerian Kesehatan (Kemenkes) Republik Indonesia, Indonesian Technical Advisory Group on Immunization (ITAGI), United Nations Children's Fund (UNICEF), dan World Health Organization (WHO) yang dilakukan pada September 2020 dan melibatkan 115.000 responden. Agar dapat meningkatkan penerimaan vaksin tersebut kepada masyarakat, pemerintah telah melakukan uji klinis ulang dan bahkan Pak Jokowi, Presiden Republik Indonesia pun melopori awalnya vaksinasi di Indonesia yang bahkan disiarkan langsung ke penjuru Indonesia agar masyarakat lebih terbuka terhadap vaksinasi Covid-19 ini. Dan cara ini berjalan lancar sehingga banyak dari mereka mulai terbuka dengan melakukan vaksinasi.

Efektivitas suatu vaksin Covid-19 dikatakan memiliki presentase sebesar $80 \%$ yang artinya jika sepuluh orang sudah divaksinasi, besar kemungkinan hanya 2 orang dari 10 orang yang akan tertular Covid-19. Pada catatan yang sama, keamanan vaksin didefinisikan sebagai kemampuannya untuk tidak menyebabkan masalah pada kesehatan, baik untuk saat ini maupun untuk masa yang akan 
datang. Ini adalah salah satu cara ampuh memutus penyebaran Covid-19. Maka dari itu segerakan bervaksin agar pandemi ini segera berakhir.

\section{Hasil Survei dan Observasi pada Substansi}

Tujuan penelitian ini adalah untuk membentuk pribadi yang saling menghargai satu sama lain dan mempererat solidaritas sesama umat beragama, memutus rantai penyebaran Covid-19 agar dapat meminimalisir korban, menciptakan lingkungan yang aman dan terhindar sepenuhnya dari pemaparan virus Covid-19.

Setelah menyelesaikan studi kasus dan observasi langsung di lapangan, tepatnya di lingkup kecamatan Sukodono, didapatkan hasil penelitian sebagai berikut. Pada kecamatan Sukodono situasi cenderung tidak kondusif. Seperti misalnya di pasar tradisional, hampir tidak ada tempat cuci tangan, tidak ada social distancing sama sekali, dan sering dijumpai juga yang menggunakan masker tetapi tidak sesuai dengan protokol. Pada masjid pun demikian, pada awalnya semua berjalan sesuai protokol kesehatan dan sangat ketat, namun lambat laun menjadi kendur. Dan bahkan saat ini sudah tidak diberlakukan social distancing saat sholat. Di lingkungan perumahan juga banyak sekali warga keluar rumah tanpa memperhatikan prokes. Hanya segelintir orang saja yang patuh dan taat pada prokes.

Setelah dilakukannya observasi pada lapangan, peneliti mengumpulkan data survei dari wawancara secara langsung maupun tidak langsung tentang tanggapan meraka terhadap penerapan protokol kesehatan didaerah sekitar. Didapatkan sekitar $77 \%$ masyarakat Sukodono beranggapan bahwa didaerah sekitarnya telah melaksanakan protokol kesehatan dengan cukup baik, dan sisanya beranggapan bahwa masih banyak warga sekitar yang tidak menerapkan prokes dengan baik karena kurangnya kesadaran masyarakat, seperti minimnya penerapan Social Distancing, penggunaan masker yang tidak benar, dan kurangnya penggunaan fasilitas cuci tangan di tempat umum.

Dilakukan pula survei tentang alasan mereka melakukan vaksinasi. Sekitar 70\% dari mereka mengatakan bahwa tujuan mereka melakukan vaksinasi adalah agar terhindar dari Covid-19. Namun sisanya memiliki pendapat alasan mereka 
97 JIE (Journal of Islamic Education)

e-ISSN: 2528-0465 (online) | Volume 7, Issue 1 | December-May 2022

p-ISSN: 2503-5363 (print)

melakukan vaksinasi hanya sekadar melakukan anjuran pemerintah, agar dapat bepergian ke tempat umum secara leluasa, dan juga karena tuntutan pekerjaan.

\section{KESIMPULAN}

Penerapan protokol kesehatan pada 77\% daerah subtansi yang disurvei menyatakan bawah; didaerah mereka menerapkan protokol kesehatan dengan baik. Kebanyakan dari mereka juga sudah melakukan vaksinasi. Tanggapan mereka dalam kondisi pandemi Covid-19 ini sangat berpengaruh, mengingat bahayanya virus covid-19. Pada awalnya masyarakat meremehkan pemberlakuan PPKM yang diarahkan pemerintah daerah, namun perilaku itu merupakan kesalahan dalam berpikir. Pasalnya untuk menghentikan rantai penyebaran covid19 yaitu dengan cara; mengikuti arahan pemerintah tentang pemberlakuan PPKM, melaksanakan vaksinasi, dan menerapkan protokol kesehatan.

\section{BIBLIOGRAFI}

[1] Aditya, A. (2014). Cara Berpikir Objektif Menurut Al-Qur'an. Jawa Barat: ArgaAditya.

[2] Aji, R. H. S. (2020). Dampak Covid-19 pada Pendidikan di Indonesia: Sekolah, Keterampilan, dan Proses Pembelajaran. Jurnal Sosial dan Budaya Syar-I, 75$), 1-10$.

[3] Alda, R. A. (2020). Analisis Bahaya Covid-19 Sebagai Upaya Pencegahan Penyebaran di Fasilitas Umum Bandara Dengan Metode Hazard Identification Risk Assessment (HIRA). Jurnal Ilmiah dan Teknik Industri Universitas Kadiri, 4(1), 15-27.

[4] Alvian, Y., \& Laudry, S. (2020). Propaganda covid-19 terhadap awareness masyarakat surabaya untuk mengikuti program kerja pemerintah. Jurnal Komunikasi Profesional, 4(1), 27-41.

[5] Anwar, S. (2022). Evaluasi Pendidikan Menuju Insan Kamil Perspektif Filsafat Islam. Jurnal Pendidikan Nusantara, 1(1), 62-76.

[6] Artama, S., Atunnisa, R., \& Brigita, M. (2021). Kepatuhan Remaja Dalam Penerapan Protokol Kesehatan Pencegahan Covid-19 Di Lingkungan Sangingloe Kecamatan Tamalatea Kabupaten Jeneponto. Jurnal IImiah Kesehatan Pencerah, 10(1), 65-72.

[7] Barak, Y. (2006). The Immune System and Happines. Autoimmunity Reviews, 5(8), 523-527.

[8] Blanchette, I., \& Richards, A. (2010). The influence of affect on higher level 
cognition: A review of research on interpretation, judgement, decision making and reasoning. Cognition and Emotion, 24(4), 561-595.

[9] Buana, D. R. (2020). Analisis Perilaku Masyarakat Indonesia dalam Menghadapi Pandemi Virus Corona (Covid-19) dan Kiat Menjaga Kesejahteraan Jiwa. Jurnal Sosial dan Budaya Syar-I, 7(3), 1-18.

[10] Corbuzer, D. (2021). Tersinggung!! - Pemuda Tersesat ft. Habib jafar \& Coki Pardede. Tanggerang: Deddy Corbuzier.

[11] Fadillah, W. I. (2021). Efektivitas Kinerja Aparatur Dalam Kebijakan Work From Home (Wfh) Pada Badan Kepegawaian Dan Pengembangan Sumber Daya Manusia Di Kabupaten Agam Provinsi Sumatera Barat. Sumedang: IPDN Jatinangor.

[12] Fira. (2021). Lima Hal yang Wajib Dijaga dalam Islam. Jakarta: Obsessionnews.

[13] Hanoatubun, S. (2020). Dampak Covid - 19 terhadap Prekonomian Indonesia. EduPsyCouns: Journal of Education, Psychology and Counseling, 2(1), 146-153.

[14] Ikhwan, A. (2021). Metode Penelitian Dasar (Mengenal Model Penelitian dan Sistematikanya). Tulungagung: STAI Muhammadiyah Tulungagung.

[15] Ikhwan, A., Anwar, S., \& Mahmudah, N. (2021). Tahsin and Tahfidz Learning System at Integrated Islamic Elementary School (SDIT) Insan Madani During the Pandemic Covid-19. Al-Hayat: Journal of Islamic Education (AJIE), 5(1), $1-11$.

[16] Law, S., Leung, A. W., \& Xu, C. (2020). Severe acute respiratory syndrome (SARS) and coronavirus disease-2019 (COVID-19): From causes to preventions in Hong Kong. International Journal of Infectious Diseses, 94, 156-163.

[17] Lufaefi. (2020). Enam Hadist Tentang Keharusan Taat pada Pemimpin. Jakarta Selatan: PT. Akurat Sentra.

[18] Maryano, A., \& Sholeh, S. (2021). Implanting Morals in The Implementation of the Distance Learning System. Edukasi: Jurnal Pendidikan Islam, 9(2), 219-228.

[19] Nashrullah, N. (2020). Qawaid Fiqhiyah: Tidak Boleh Membahayakan Nyawa Orang Lain.

[20] Nasir, A. K., \& Prastowo, A. (2021). Implementasi Teknik Penilaian Blended Learning Pada Keterampilan Pembelajaran Fiqih Masa Pandemi Covid-19. JIE: Journal of Islamic Edication, 6(2), 173-184.

[21] Nicola, M., Alsafi, Z., Sohrabi, C., Kerwan, A., Al-Jabir, A., Iosifidis, C., ... Agha, R. (2020). The Socio-Economic Implications of the Coronavirus Pandemic (COVID-19): A Review. International Journal of Surgery, 78, 185193.

[22] Nugroho, S. A., \& Hidayat, I. N. (2021). Efektivitas Dan Keamanan Vaksin 
99 JIE (Journal of Islamic Education)

e-ISSN: 2528-0465 (online) | Volume 7, Issue 1 | December-May 2022

p-ISSN: 2503-5363 (print)

Covid-19: Studi Refrensi. Jurnal Keperawatan Profesional (JKP), 9(2), 1-26.

[23] Paramadina, D. R. (2021). Edukasi Bahaya Covid-19 Daerah Pedesaan di Era New Normal. Jurnal Pembelajaran Pemberdayaan Masyarakat, 2(1), 35-40.

[24] Perdana, R. (2020). Analisis Dampak Work From Home Terhadap Gejala Stress dan Keluhan Otot Rangka. Sumatera Utara: Repositori Institut Universitas Sumatera Utara.

[25] Permana, B. G. (2021). Efek Bias Kognitif dalam Pengambilan Keputusan dan Cara Mencegahnya.

[26] Pinasti, F. D. A. (2020). Analisis Dampak Pandemi Corona Virus Terhadap Tingkat Kesadaran Masyarakat dalam Penerapan Protokol Kesehatan. Wellness and Healthy Magazine, 2(2), 237-249.

[27] Purnamasari, I., \& Rahayani, A. E. (2020). Tingkat Pengetahuan dan Perilaku Masyarakat Kabupaten Wonosobo Tentang Covid -19. Jurnal IImiah Kesehatan, 3(1), 33-42.

[28] Sa'adi, Z. T. (2020). Memelihara Kehidupan Manusia. Jakarta Pusat: ementerian Agama RI.

[29] Santoso, T. (2021). Dua Ayat Al-Qur'an Tentang Perintah untuk Menjaga Diri. Jember: Portal Jember.

[30] Setyawan, F. E. B., \& Lestari, R. (2020). Challenges Of Stay-At-Home Policy Implementation During The Coronavirus (Covid-19) Pandemic In Indonesia. Jurnal Administrasi Kesehatan Indonesia (JAKI), 8(1), 1-6.

[31] Sharot, T. (2011). The Optimism Bias. Current Biology, 21(23), 941-945.

[32] Suspahariati, S., \& Susilawati., R. (2020). Penerapan Sistem WFH (Work From Home) dan Dampaknya terhadap Kinerja Staf dan Dosen Unipdu Jombang selama Pandemi Covid-19. Jurnal Manajemen dan Pendidikan Islam, 6(2), 229-240.

[33] Wiranti, Sriatmi, A., \& Kusumastuti, W. (2020). Determinan Kepatuhan Masyarakat Kota Depok terhadap Kebijakan Pembatasan Sosial Berskala Besar dalam Pencegahan Covid-19. Jurnal Kebijakan Kesehatan Indonesia, 9(3), 117-124.

[34] Yuliana. (2020). Corona Virus Diseases (Covid-19): Sebuah tinjauan literatur. Wellness and Healthy Magazine, 2(1), 1-6.

[35] Yunus, N. R., \& Rezki, A. (2020). Kebijakan Pemberlakuan Lock Down Sebagai Antisipasi Penyebaran Corona Virus Covid-19. Jurnal Sosial dan Budaya Syar-I, 7(3), 227-238. 